\title{
Toxicological Safety Assessment of Molluscicides Against Non-target Aquatic Biota; Colisa fasciatus
}

\author{
Neelam Soni, Vinay Kumar Singh* \\ Malacology laboratory, Department of Zoology, DDU Gorakhpur University Gorakhpur 273009 (U.P.), India \\ * Corresponding author email: vinaygkpuniv@gmail.com
}

Received: 09 February 2019 / Revised: 13 April 2019 / Accepted: 19 April 2019 / Published: 30 April 2019

\begin{abstract}
Plants Terminalia arjuna and Tamarindus indica are known to have a significant molluscicidal potential to control the population of vector snails. Since the molluscicides are considered an emerging pollutant and are frequently detected in surface water bodies and found to be a great threat for aquatic biota. Hence, the main objective of this research is to critically evaluate the ectotoxicological and chronic effect of plant-derived molluscicides on other aquatic biotas. With these references this study deals with the safety measurement of molluscicides arjnolic acid, saponin and procynadine from T. arjuna and T. Indica against the fish Colisa fasciatus which share the same habitat with snails. The result of toxicity experiment reveals that fishes showed no mortality against $24 \mathrm{~h} \mathrm{LC} 90$ (against L. acuminata and I. exustus) up to $96 \mathrm{~h}$ exposure duration. The enzyme bioassays of these molluscicides on the nervous tissue of fish showed no significant effect on key enzymes Acetylcholinesterase, acid and alkaline phosphates activity in comparison to control group of fishes. These results indicated that the application of arjunolic acid, saponin, and procynadine derive from plant T. arjuna and T. indica at its maximum concentration (24h LC 90 of L. acuminata and I. exustus) and exposure duration (96h) did not cause any mortality or treatment-related enzymes inactivity in fishes. The study conclusively proved the ecotoxicological and chronic safety of plant-derived molluscicides arjunolic acid, saponin, and procynadine on non-target animals in the aquatic environment.
\end{abstract}

Keywords: Molluscicides; Fish; Ectotoxicology; snails; Plants; Environmental safety; Snails

\section{Introduction}

The use of the molluscicides has been increased considerably to reduce the incident of fasciolosis, a food and waterborne disease caused by fasciola species commonly referred as liver flukes [1]. Among these molluscicides, plants derived molluscicides were commonly used because of their rapid biodegradability and non-persistent nature [2], [3], [4] [5]. These molluscicides, which frequently entered in the aquatic ecosystem through aquatic environment operations adversely, affect non-target animals such as fish [6], [7]. Medicinal plants are known to play an essential role in traditional and conventional medicine preparation [8]. The plant of Terminalia arjuna and Tamarindus indica are known to have high medicinal value in Indian traditional medicine [9], [10], [11], [12]. Since then the essays with this approach the two indigenous medicinal plants Terminalia arjuna and Tamarindus indica have successfully tested for their molluscicidal activity [2], [3], [12]. The molluscicidal component extracted from these two plant i.e arjunolic acid, saponin and procynadine significantly affect the brain tissue of targeted snails by affecting key enzymes AChE, ACP and ALP activities [12], [13]. The present study was carried out to explore the application safety of these molluscicidal drugs on non target aquatic biota such as, fish Colisa fasciatus and also study the effect of these molluscicidal drugs on the brain tissue of fishes, which share the same habitat with the fasciola vector snails i.e. Lymnaea acuminata and Indoplanorbis exustus. 


\section{Materials and Methods}

\subsection{Collection of Experimental Animals and Plant}

The Fish Colisa fasciatus ( $5.74 \pm 0.26 \mathrm{~cm}$ in length) were collected from Ramgarh lake of Gorakhpur District. The collected fish were stored in glass aquaria containing dechlorinated tap water for $72 \mathrm{~h}$ in order to acclimatize these to laboratory conditions. Bark/seed of Tamarindus indica (imli) and Terminalia arjuna were collected from Botanical garden of D.D.U. Gorakhpur University campus, Gorakhpur India and identified by retired Prof. S.K. Singh, plant taxonomist, Department of Botany D.D.U. Gorakhpur University Gorakhpur India.

\subsection{Preparation of Column Purified Fraction for Experimental Analysis}

$50 \mathrm{ml}$ ethanol extract of each plant preparation i.e. bark, seed of $T$. indica and bark of $T$. arjuna were subjected to silica gel (60-120) mesh Qualigens glass, Precious Electro Chemindus Industry Privet Limited, Mumbai, India) Chromatography through $95 \times 45 \mathrm{~cm}$ column. Five milliliters fractions of elutents were eluted with 95\% ethanol for each column preparation. Ethanol was evaporated under vacuum and the remaining solids obtained from all $5 \mathrm{ml}$ elutents were used for experimental study.

\subsection{Pure Compounds}

Saponin (Sopogenin-10\%) Procynadine (cis, trans"-4,8"-Bi-(3,3',4',5,7-Pentahydroxyflavane), Arjunolic (2,3,23- Trihydrooxyolean-12-en, 28oic acid) and purchased from Sigma Chemical Co., USA.

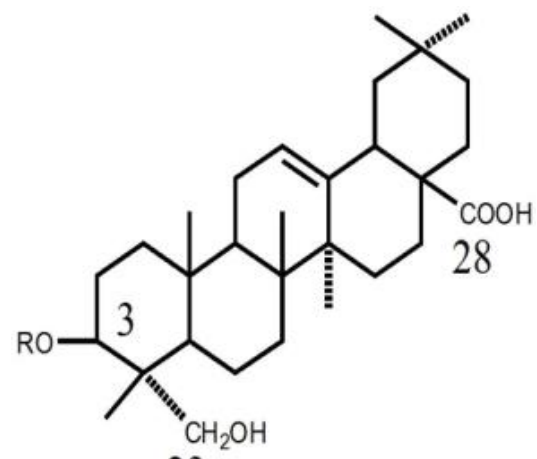

23

Saponin

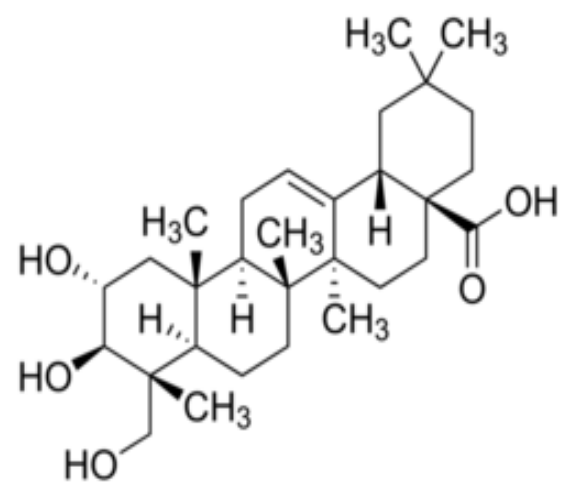

Arjunolic Acid<smiles>Oc1ccc2c(c1)O[C@H](c1ccc(O)c(O)c1)[C@H](O)[C@@H]2c1c(O)cc(O)c2c1O[C@H](c1ccc(O)c(O)c1)[C@H](O)C2</smiles>

Procynadine

\subsection{Acute Lethal Fish Toxicity Test}

Toxicity of column purified fractions and active (pure) components of Tamarindus indica and Terminalia arjuna were tested against the fish Colisa fasciatus to elucidate the toxic effect of molluscicides on other non target animal in aquatic environment. Ten fish were apportioned into each group and confined for an exposure of molluscicides at the interval of $96 \mathrm{~h}$ of dose of 24h $\mathrm{LC}_{90}$ (L. acuminata and I. exustus). Control group of fishes did not receive any treatment with all similar condition.

\subsection{Enzyme Bioassay}

Ten experimental fishes were kept in a glass aquarium containing $5 \mathrm{~L}$ of dechlorinated tap water. Six aquaria were set up for each concentration of $24 \mathrm{~h} \mathrm{LC} 90$ ((L. acuminata and $I$. exustus) for $96 \mathrm{~h}$ exposure period of different column purified fractions and active components of viz- arjunolic, saponin and procynadine of $T$. arjuna bark and T. Indica bark and seed (Table.1). Control aquarium contained only equal volume of dechlorinated tap water without treatment. After termination of the treatment fishes were 
Table 1: Toxicity of $24 \mathrm{~h} L C_{90}$ (L. acuminata and I. exustus) of column purified fractions and active component of T. arjuna bark and T. indica bark/seed against the fish Colisa fasciatus at different exposure period.

\begin{tabular}{|c|c|c|}
\hline Molluscicides & $\begin{array}{c}\text { 24h LC90 (mg/l) } \\
\text { against fish Colisa fasciatus }\end{array}$ & $\begin{array}{c}\text { 24h LC90 (mg/l) (I. exustus) } \\
\text { against fish Colisa fasciatus }\end{array}$ \\
\hline T. arjuna bark (CPF) & 20.41 & 161.56 \\
\hline Arjunolic acid & 26.82 & 66.53 \\
\hline T. indica bark (CPF) & 28.96 & 167.14 \\
\hline Saponin & 28.17 & 150.45 \\
\hline T. indica seed (CPF) & 4.68 & 82.38 \\
\hline Procynadine & 5.13 & 62.68 \\
\hline
\end{tabular}

washed with water and nervous tissue was quickly taken out and collected on ice trey for enzymatic analysis. The experiment was performed in treated as well as in control group of test animal.

\subsubsection{Acetylcholinesterase}

Acetylcholinesterase activity was measured according to the method of Ellman et al, [14]. Fifty milligrams of nervous tissue of Colisa fasciatus was taken around the buccal mass and homogenized in $1.0 \mathrm{ml}$ of $0.1 \mathrm{M}$ phosphate buffer $\mathrm{pH} 8.0$ for 5 minutes in an ice bath then centrifuged at $1000 \mathrm{~g}$ for 30 minutes at $4^{\circ} \mathrm{C}$. The supernatant was used as an enzyme source. Enzyme using an incubation mixture consisting of $0.1 \mathrm{~mL}$ of enzyme source, $2.9 \mathrm{~mL}$ of $0.1 \mathrm{M}$ buffer $\mathrm{pH} 8.0,0.1 \mathrm{ml}$ of chromogenic agent DTNB (5,5-dithio-bis-2-nitrobenzoic acid), and $0.02 \mathrm{~mL}$ of freshly prepared ATChI (acetylthiocholine iodide) solution in distilled water. The change in optical density at $412 \mathrm{~nm}$ was recorded for 3 minutes after every 30 second interval at $25^{\circ} \mathrm{C}$. Enzyme activity has been expressed as $\mu$ mole "SH" hydrolyzed $\mathrm{min} / \mathrm{mg} /$ protein.

\subsubsection{Acid Phosphatase}

Assays of acid and alkaline phosphatase activities were carried out by the method of Bergmeyer, [15]. Tissue homogenate $(2 \% \mathrm{~W} / \mathrm{V})$ was prepared in ice cold $0.9 \% \mathrm{NaCl}$ and centrifuged at $5000 \mathrm{~g}$ for 15 minutes at $4^{\circ} \mathrm{C}$. Supernatant was used as an enzyme source. Standard curves were drawn with p-nitrophenol.
$0.2 \mathrm{ml}$ of enzyme source was added to $1.0 \mathrm{ml}$ of acid buffer substrate $(0.41 \mathrm{~g}$ citric acid, $1.125 \mathrm{~g}$ sodium citrate, and $165 \mathrm{mg}$ 4-nitrophenyl phosphatase sodium salt to $100 \mathrm{ml}$ of double distilled water) pre-incubated at $37^{\circ} \mathrm{C}$ for 10 minutes. The incubation mixture was mixed thoroughly and incubated for 30 minutes at $37^{\circ} \mathrm{C}$. $4.0 \mathrm{ml}$ of $0.1 \mathrm{NaOH}$ was then added to the incubation mixture. The yellow colour developed due to the formation of p-nitrophenol was determined by spectrophotometer at $405 \mathrm{~nm}$, standard curve was drawn with different concentration of 4- nitro phenol. The ACP activity has been expressed as $\mu$ mole substrate hydrolyzed $/ 30 \mathrm{~min} / \mathrm{mg}$ protein.

\subsubsection{Alkaline Phosphatase}

To determine the hydrolytic activity of alkaline phosphatases, $0.1 \mathrm{ml}$ of enzyme source was added to $1.0 \mathrm{ml}$ of pre-incubated $(10 \mathrm{~min})$ alkaline buffer substrate $(375 \mathrm{mg}$ glycine, $10 \mathrm{mg}$ $\mathrm{MgCl}_{2} \cdot 6 \mathrm{H}_{2} \mathrm{O}, 165 \mathrm{mg}$ 4-nitrophenol phosphate sodium salt in $42 \mathrm{ml}$ of $0.1 \mathrm{~N} \mathrm{NaOH}$ and a mixture was made up to $100 \mathrm{ml}$ with double distilled water). The incubation mixture was mixed thoroughly and incubated for 30 minutes at $37^{\circ} \mathrm{C} .10 \mathrm{ml}$ of $0.02 \mathrm{~N} \mathrm{NaOH}$ was then added to the incubation mixture. Reaction was stopped by the addition of an excess of $\mathrm{NaOH}$ solution. The yellow colour developed due to the formation of p-nitro phenyl phosphate. The activity of alkaline phosphatase was determined calorimetrically at $405 \mathrm{~nm}$; it has been expressed as $\mu$ mole subtracts hydrolyzed $/ 30 \mathrm{~min} / \mathrm{mg}$ protein. 
Table 2: In vivo effect of 24 h exposure of $80 \% 24 \mathrm{~h}$ LC 90 (against L. acuminata) column purified fraction and active component of T. arjuna and T. indica bark/seed on AChE, ACP and ALP activities in the nervous tissue of Fish Colisa fasciatus.

\begin{tabular}{|c|c|c|c|c|}
\hline Treatments & $\begin{array}{c}\text { Concentration } \\
(\mathrm{mg} / \mathrm{l}) \\
80 \% \text { of } 24 \mathrm{~h} \mathrm{LC} \mathrm{LC}_{90}\end{array}$ & $\begin{array}{c}\text { AChE } \\
\mu \text { mole 'SH' } \\
\text { hydrolyzed } / \mathrm{min} / \mathrm{mg} \\
\text { protein }\end{array}$ & $\begin{array}{c}\text { ACP } \\
\mu \text { mole substrate } \\
\text { hydrolyzed } \\
\text { /30min/mg protein }\end{array}$ & $\begin{array}{c}\text { ALP } \\
\mu \text { mole substrate } \\
\text { hydrolyzed } \\
\text { /30min/mg protein }\end{array}$ \\
\hline Control & - & $\begin{array}{c}0.836 \pm 0.04 \\
(100)\end{array}$ & $\begin{array}{c}56.95 \pm 0.84 \\
(100)\end{array}$ & $\begin{array}{c}49.10 \pm 0.83 \\
(100)\end{array}$ \\
\hline $\begin{array}{l}\text { T. arjuna bark } \\
\text { (CPF) }\end{array}$ & $16.32 \mathrm{mg} / \mathrm{l}$ & $\begin{array}{l}0.804 \pm 0.26 \\
\quad(96.17)\end{array}$ & $\begin{array}{c}54.85 \pm 0.96 \\
(96.31)\end{array}$ & $\begin{array}{c}47.17 \pm 0.92 \\
(96.99)\end{array}$ \\
\hline Arjunolic acid & $21.45 \mathrm{mg} / \mathrm{l}$ & $\begin{array}{l}0.815 \pm 0.07 \\
\quad(97.48)\end{array}$ & $\begin{array}{l}55.11 \pm 0.85 \\
\quad(96.76)\end{array}$ & $\begin{array}{l}47.19 \pm 0.85 \\
\quad(96.10)\end{array}$ \\
\hline $\begin{array}{l}\text { T. indica bark } \\
\text { (CPF) }\end{array}$ & $23.16 \mathrm{mg} / \mathrm{l}$ & $\begin{array}{l}0.818 \pm 0.01 \\
\quad(97.84)\end{array}$ & $\begin{array}{l}55.29 \pm 0.85 \\
(98.82)\end{array}$ & $\begin{array}{c}46.43 \pm 0.87 \\
(94.56)\end{array}$ \\
\hline Saponin & $22.53 \mathrm{mg} / \mathrm{l}$ & $\begin{array}{l}0.821 \pm 0.05 \\
\quad(98.20)\end{array}$ & $\begin{array}{l}55.71 \pm 0.91 \\
\quad(97.82)\end{array}$ & $\begin{array}{c}46.83 \pm 0.89 \\
(95.37)\end{array}$ \\
\hline $\begin{array}{l}\text { T. indica seed } \\
(\mathrm{CPF})\end{array}$ & $3.74 \mathrm{mg} / \mathrm{l}$ & $\begin{array}{l}0.798 \pm 0.08 \\
\quad(95.45)\end{array}$ & $\begin{array}{l}53.87 \pm 0.95 \\
(94.59)\end{array}$ & $\begin{array}{l}48.58 \pm 0.95 \\
(98.94)\end{array}$ \\
\hline Procynadine & $4.10 \mathrm{mg} / \mathrm{l}$ & $\begin{array}{l}0.809 \pm 0.01 \\
\quad(96.77)\end{array}$ & $\begin{array}{l}55.09 \pm 0.95 \\
(96.73)\end{array}$ & $\begin{array}{l}48.04 \pm 0.95 \\
(98.57)\end{array}$ \\
\hline
\end{tabular}

Values are mean \pm SE of Six replicates. Values in parentheses indicate percent enzyme activity with control taken as $100 \%$. Concentrations $(\mathrm{W} / \mathrm{V})$ have been expressed as final concentration in aquarium water. Non-significant ( $\mathrm{p}>0.05)$ when student's t-test was used for locating difference between treated and control group of snails. Abbreviations- T. arjuna-Terminalia arjuna, T. indica-Tamarindus indica, CPF-

\subsubsection{Protein}

Quantitative assessment of protein was made according to procedure of Lowry et al [16].

\subsection{Statistical Analysis}

Each experimental was replicated at least six times and results were expressed as mean $\pm \mathrm{SE}$ of Six replicates. Student's test was applied between control and treated groups to locate significant $(\mathrm{p}<0.05)$ variations [17].

\section{Results}

\subsection{Toxicity Experiment}

The result of the toxicity experiments revels that there was no mortality in fish Colisa fasciatus exposed to $24 \mathrm{~h} \mathrm{LC}_{90}$ (against L. acuminata and $I$. exustus) of all column purified fractions and active molluscicidal components viz arjunolic acid, saponin and procynadine of T. arjuna and T. indica up to 96 h of exposure period (Table 1). Even not any behavioural changes were noted after the exposure of molluscicides.

\subsection{Biochemical measurement}

In vivo effect of plant preparations on enzymatic activities in the nervous tissue of fish Colisa fasciatus

In control group of experiments acetylcholinesterase, acid and alkaline phosphatase activities activity in the nervous tissue of Colisa fasciatus were $0.836 \mu$ mole 'SH' hydrolyzed/min/mg proteins, $56.95 \mu$ mole substrate hydrolyzed $/ 30 \mathrm{~min} / \mathrm{mg}$ protein and $49.10 \mu$ mole substrate hydrolyzed $/ 30 \mathrm{~min} / \mathrm{mg}$ protein, respectively (Table 2). In vivo treatments, $24 \mathrm{~h}$ exposure of $24 \mathrm{~h} \mathrm{LC}_{90}$ (against L. acuminata) of column purified fraction (96.17\% of control) and arjunolic acid (97.48\% of control), of $T$. arjuna bark, column purified fraction $(97.84 \%$ of control) and saponin (98.20\% of control) of $T$. indica bark, and column purified fraction (95.45\% of control) and procynadine ( $96.77 \%$ of control) of $T$. indica seed caused no significant $(\mathrm{p}>0.05)$ inhibition in AChE activity (Table 2, Figure 1). 


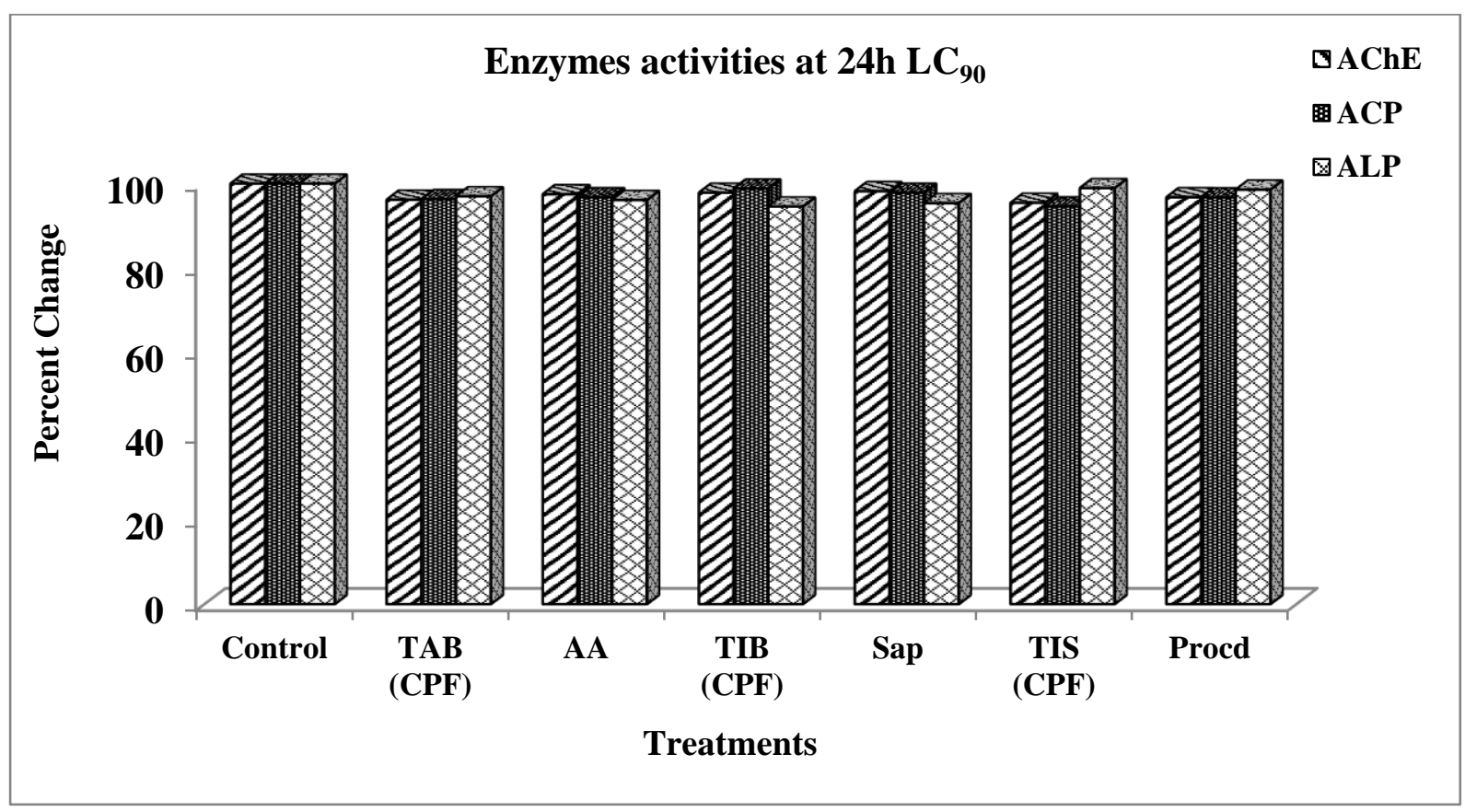

Figure 1: Histogram showing in vivo effect of 24 h exposure of $80 \%$ of $24 \mathrm{~h} L C_{90}$ (against L. acuminata) of column purified fractions and active components (arjunolic acid of T. arjuna bark), (saponin of T. indica bark),

(procynadine of T. indica seed) on the AChE, ACP and ALP activities in the nervous tissue of fish Colisa fasciatus. Abbreviations; TAB (CPF)- Terminalia arjuna bark (column purified fraction); AA-Arjunolic acid; TIB (CPF)-Tamarindus indica bark (column purified fraction); Sap-Saponin; TIS (CPF)-Tamarindus indica seed (column purified fraction); Procd, Procynadine.

Non-significant changes were also noticed in ACP inhibition by column purified fraction (96.31\% of control) and arjunolic acid $(96.76 \%$ of control), of $T$. arjuna bark, column purified fraction $(98.82 \%$ of control) and saponin ( $97.82 \%$ of control) of T. indica bark, and column purified fraction $(94.59 \%$ of control) and procynadine $(96.73 \%$ of control) of T. indica seed (Figure 1). Inhibition of ALP activities in the nervous tissue of fish Colisa fasciatus by column purified fraction $(96.99 \%$ of control) and arjunolic acid (96.10\% of control), of T. arjuna bark, column purified fraction (94.56 of control) and saponin (95.37\% of control) of T. indica bark, and column purified fraction (98.94 of control) and procynadine ( $98.57 \%$ of control) of T. indica seed was not significant ( $p>0.05$ ) (Fig 1)

Student's t-test was applied between treated and control group of animals to determined significant $(\mathrm{p}<0.05)$ variations.

\section{Discussion}

The application of environmental toxicology studies on non mammalian vertebrates is rapidly expanding, and for aquatic system, fish have become indicators to evaluate the effect of noxious compound. Synthetic molluscicides was known for knock-down effect in controlling the population of harmful gastropod, however adverse effect of the synthetic molluscicides on fishes as well as to other non target organisms and great threat to ecosystem, have stimulated the interest in the search for plant derived molluscicides [18]. The plants are virtually inexhaustible natural resource of structurally diverse and biologically active substances [19], [20]. Plant molluscicides are now gaining great importance because they are economic, effective, and safe to non-target animal and culturally more acceptable [21], [22]. Two indigenous medicinal plants Terminalia arjuna (Family-Combretaceae) and Tamarindus indica (Family- Leguminosae) earlier tested for its molluscicidal activity against $L$. acuminata and $I$. exustus. The active component i.e. arjunolic acid, saponin and procynadine present in the plants was responsible for its toxicological action against snails [2], [3], [12], [13]. The result of the present study clearly 
demonstrated that the column purified fractions and their active molluscicidal components of both the plants $\left(24 \mathrm{~h} \mathrm{LC}_{90}\right.$ against $L$. acuminata and I. exustus) does not show any toxic effect in fish Colisa fasciatus as no mortality was reported up to $96 \mathrm{~h}$ exposure period, because the concentration of molluscicides used to kill the snails $L$. acuminata and $I$. exustus was too low to cause any mortality in fishes. In vivo exposure of $80 \%$ of $24 \mathrm{~h} \mathrm{LC} 90$ of column purified fractions and active constituents viz- arjunolic acid, saponin and procynadine of $T$. arjuna bark and $T$. indica bark and seed caused no significant $(p>0.05)$ inhibition in AChE, ACP and ALP activities in the nervous tissue of fish Colisa fasciatus. The result of this experiment clearly indicates the tolerance limits and safety of these molluscicides against non targeted animals.

\section{Conclusions}

From present study it can be concluded that plant of $T$. arjuna and $T$. indica can be used as potent molluscicides since the concentration used to kill 90\% of the snails were not toxic to the fish Colisa fasciatus which share the same habitat with the snails. These indigenous plant molluscicides might be a valuable, environmentally safe and sound source of among the plant derived molluscicides and may be helpful to combat fasciolosis in endemic areas by interrupting the parasitic life cycle via control of snail population without affecting the population of non targets animals.

\section{Declarations}

\subsection{Study Limitations}

The finding of the study has been seen under the light of potential limitations such as time cast, convenient sampling of experimental animal which may not be representative of actual population and a large number of environmental factors that interpret with the result of the study.

\subsection{Acknowledgement}

The authors are grateful to Prof. D.K. Singh (Department of Zoology, DDU Gorakhpur University, Gorakhpur) for his valuable suggestion in the preparation of final manuscript.

\subsection{Ethical Consideration}

The authors declare that they have followed the protocols of their work centre on the publication of humans \& animals related study.

\subsection{Funding Source:}

None

\subsection{Competing Interests}

The authors declare that they have no competing interest.

\section{How to Cite this Article:}

N. Soni and V. Singh, "Toxicological Safety Assessment of Molluscicides Against Non-target Aquatic Biota; Colisa fasciatus", Int. Ann. Sci., vol. 7, no. 1, pp. 21-27, Apr. 2019. doi:10.21467/ias.7.1.21-27

\section{References}

[1] M. Meshesha and W. Tesfaye, "Prevalence of fasciolosis in the cattle slathered at Honsana Muncipal Abattoir, Southern Ethiopia" International Journal of Advance Research in Biological Science, vol. 4, no. 2, pp 40-46, 2017.

[2] N. Soni and V.K. Singh, "Molluscicidal activity of Tamarindus indica and Terminalia arjuna against Indoplanorbis exustus: A causative agent of Trematodiasis. Scientia Agriculture, vol.12, pp 163-170, 2015

[3] N. Soni and V.K. Singh, "Screening of molluscicidal potential of indigenous medicinal plants Terminalia arjuna and Tamarindus indica against fasciolosis vector: Lymnaea acuminata". Asian Journal of Science and Technology. Vol. 8 no. 8, pp5256-5261. 2017.

[4] D. Chaturvedi and V.K. Singh, "Toxicity of Chlorophylline against Lymnaea acuminata at different wavelength of visible light”. Tropical Life Sciences Research, vol. 27 no. 2, pp 25-36, 2016.

[5] K. Singh, D.K.Singh, and V. K. Singh, "Chlorophylline treatment against Lymnaea acuminata: a new tool in fasciolosis control”. Pharmacognosy Journal, vol. 9 no. 5, pp 594-598.2017. [6] S.L. Kela, R.A. Oqunsusi, V.C. Ogubogu and N. Nwude, "Screening of some Nigerians plants for molluscicidal activity" Revue d' elevagave et de medicine veterinaire des pays tropicaux, vol. 42no. 2, pp 195-202.1989.

[7] B.B Mosta-fa, F.A. El-deeb, N.M Ismail and K.M. el-Said, "Impact of some plant and synthetic molluscicides on fresh water snails and fish". Journal of Egyptian Society of Parasitology, vol. 35 no. 3, pp 898-1007.2005

[8] A. Amalraj and S. Gopi, "Medicinal properties of Terminalia arjuna (Roxb) Wight \& Arn”. Journal of Traditional and Complimentary Medicine, vol. 7, pp 65-78.2017

[9] J.A Riberio, A.C. Serquiz, P.F. Silva, P.B. Barbosa, T.B. Sampaio, R.F. Araujo junior A.S. Oliveira, R.J. Machado, B.L. Maciel, A.F.mUchoa, E.A. Santos, and A.H. Morais, "Trypsin inhibitor from Tamarindus indica seeds Linn. reduced weight gain cholecystokinin levels". Clinics (Sao Paulo), vol. 70 no. 2, pp136.2015

[10] T. Javed, S. Riaz, M. Uzair, G. Mustafa, A. Mohyuddin and B.C. Ahamad, "Biological activity of Terminalia arjuna on human pathogenic microorganisms." Pakistan Journal of Pharmacology Research, vol, 2 no. 1, pp 23.2016 
Soni et al., Int. Ann. Sci.; Vol. 7, Issue 1, pp: 21-27, 2019

[11] S. Zohrameena, M. Mujahid, P. Bagga, M. Khalid, H. Noorul, A. Nesar, and P. Saba, "Medicinal uses and pharmacological activity of Tamarindus indica". World Journal of Pharmacological Science, vol. 5 no. 2), pp. 121-137.2017

[12] N. Soni, D.K. Singh and V.K. Singh, "Inhibition kinetics of acetylcholinesterase and phosphatises by the active constituents of Terminalia arjuna and Tamarindus indica in the cerebral ganglion of Lymnaea acuminata". Pharmacognosy Journal, vol 9. NO.2, PP148-156.

[13] N. Soni, D.K. Singh and V.K. Singh, "HPLC characterization of molluscicidal component of Tamarindus indica and its mode of action on nervous tissue of Lymnaea acuminata" journal of Ayurveda and Integrative Medicine. \{online first),1-11 Elsevier. IF-0.98.2018

[14] G.L. Ellman, K.D. Courtney, V. Andres, and R.M.A. Featherstone, "New rapid colorimetric determination of acetylcholinesterase activity" Biochemistry Pharmacology, vol. 7, pp88-95.1961

[15] U.H. Bergmeyer, "Methods of enzymatic analysis" Academic Press: New York, pp1129.1967.

[16] O.H. Lowry, N.J. Rosenbrough, A.L. Farr and R.J. Randall, "Protein measurement with the folin phenol reagents" Journal of Biological Chemistry, vol. 193, pp. 265-275.1951

and food consumption and increased plasmatic

Publish your research article in AIJR journals-

$\checkmark$ Online Submission and Tracking

$\checkmark$ Peer-Reviewed

$\checkmark$ Rapid decision

$\checkmark \quad$ Immediate Publication after acceptance

$\checkmark$ Articles freely available online

$\checkmark \quad$ Retain full copyright of your article.

Submit your article at journals.aijr.in
[17] R.R. Sokal, and F.J. Rohlf, "Introduction to Biostatistics" San Francisco: W.H. Freeman.pp 225-229.1955

[18] A. Prakash, J. Rao, and V. Nandagopal, "Managing resistance to insecticides is a key for the future of crop protection" Journal of Biopesticides, vol 1, pp.154-169.2008

[19] U. Istvan, "Semi-natural products and related substances and alleged botanical pesticides" Pest Management Science, vol. 56 no. 8, pp, 703-705.2000.

[20] J. Shahi and A. Singh, "Comparative study on piscicidal activity of synthetic pesticides and plant origin piscicides, to fish Channa punctatus". World Journal of Zoology, vol. 5 no.1, pp. 20-24.2010.

[21] D. Chaturvedi and V.K. Singh, "Assessment the effect of photodynamic Chlorophylline on biochemical changes in the cerebral ganglion of Lymnaea acuminata" International Journal of Pharma Science and Research. Vol. 8, no.5, pp 68-75.2017

[22] G. Prabhakaran, S.J. Bhore, and M. Ravichandran, "Development and evaluation of poly herbal molluscicides extract for control of apple snail (Pomacea maculata)". Agriculture, vol. 7, pp. 22, 2017.

\section{Publish your books with AIJR publisher-}

$\checkmark$ Publish with ISBN and DOI.

$\checkmark$ Publish Thesis/Dissertation as Monograph.

$\checkmark$ Publish Book Monograph.

$\checkmark$ Publish Edited Volume/ Book.

$\checkmark$ Publish Conference Proceedings

$\checkmark$ Retain full copyright of your books.

Submit your manuscript at books.aijr.org 